\title{
LEAD ISOTOPIC RATIO DETERMINATION IN CAVE SEDIMENTS USING TRIPLE-QUADRUPOLE INDUCTIVELY COUPLED PLASMA MASS SPECTROMETRY
}

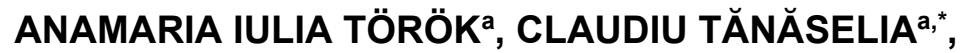 \\ ANA MOLDOVAN ${ }^{a, b}$, BOGDAN ANGYUS ${ }^{a, c}$, ERIKA ANDREA LEVEI ${ }^{a}$, \\ CECILIA ROMANa
}

\begin{abstract}
Lead isotopic ratio determination is significantly affected by the isobaric interference of mercury $\left({ }^{204} \mathrm{Hg}\right)$, thus many studies lack ${ }^{204} \mathrm{~Pb} /{ }^{206} \mathrm{~Pb}$ values. Removal of ${ }^{204} \mathrm{Hg}$ from sample is resource consuming, while mathematical correction can be employed if the $\mathrm{Hg}$ isotope ratio in the sample is known. Triple quadrupole inductively coupled plasma mass spectrometry (TQ-ICP-MS) offers a mechanism for removing the ${ }^{204} \mathrm{Hg}$, by pressurizing the reaction cell with ammonia, that reacts with ${ }^{204} \mathrm{Hg}$ positively charged ions rendering them neutral, thus filtering them out and removing them from the ion beam. The $\mathrm{Pb}$ isotope ratio determination can be used as "fingerprint" to identify the sources of contamination and environmental pollution. The method developed based on this mechanism was used for $\mathrm{Pb}$ isotopic ratio determination in cave sediment samples. Relative standard deviation of this method was between $0.36 \%-0.59 \%$.
\end{abstract}

Keywords: ICP-MS, Pb isotopic ratio, lead, cave sediments, triple-quadrupole

\section{INTRODUCTION}

Lead $(\mathrm{Pb})$ is the $36^{\text {th }}$ most abundant element in the Earth's crust (16 ppm crustal abundance), occurring with four naturally occurring stable isotopes: ${ }^{204} \mathrm{~Pb}(1.4 \%$ abundance $),{ }^{206} \mathrm{~Pb}(24.1 \%$ abundance $){ }^{207} \mathrm{~Pb}(22.1 \%$ abundance $)$

a INCDO-INOE2000, Research Institute for Analytical Instrumentation, 67 Donath, RO-400293, Cluj-Napoca, Romania

b Technical University, Faculty of Materials and Environmental Engineering, 103-105 Muncii Boulevard, 400641 Cluj-Napoca, Romania

c Babes-Bolyai University, Faculty of Chemistry and Chemical Engineering, 11 Arany Janos, 400028 Cluj-Napoca, Romania

Corresponding author: claudiu.tanaselia@icia.ro 
and ${ }^{208} \mathrm{~Pb}(52.4 \%$ abundance $)$, with ${ }^{204} \mathrm{~Pb}$ being the only isotope that is not radiogenic. The other three isotopes are the products of the radioactive decay of uranium $\left({ }^{235} \mathrm{U},{ }^{238} \mathrm{U}\right)$ or thorium $\left({ }^{232} \mathrm{Th}\right)$ [1]. Hence the geographically $\mathrm{Pb}$ abundance is correlated with former $\mathrm{U}$ and Th ore deposits, thus making $\mathrm{Pb}$ isotopic ratio determination an excellent geological tracer and an important geochronometer [2-4].

$\mathrm{Pb}$ isotopic measurements are used to determine the age of meteorites, Earth and other planetary bodies (Mars and Moon) [2]. Also, it can offer information on geochemical origins by "fingerprinting" minerals, lavas and pollutants as potential $\mathrm{Pb}$ sources and on the pathways by which $\mathrm{Pb}$ enters into the environment $[5,6]$. Moreover, $\mathrm{Pb}$ isotopic studies can offer valuable information on the geogenic or anthropogenic sources of $\mathrm{Pb}$ in various environmental matrices (water, soil, sediments, rocks, plants etc.). $\mathrm{Pb}$ is considered one of the most toxic heavy elements that occurs naturally in the environment, with no known function in the human body [7]. Pb occurs in the atmosphere as fine particulate $(<1 \mu \mathrm{m})$ from anthropogenic sources, and it can also be found in ore deposits such as galena ( $\mathrm{PbS})$, anglesite $\left(\mathrm{PbSO}_{4}\right)$, cerussite $\left(\mathrm{PbCO}_{3}\right)$, or minimum $\left(\mathrm{Pb}_{3} \mathrm{O}_{4}\right)$ [3]. Distribution in the environment takes places through a series of complete well-balanced chemical and physical processes such as weathering, runoff, precipitation, stream/river flow, erosion, though which $\mathrm{Pb}$ is transferred to atmosphere (air, dust), hydrosphere (water), lithosphere (soil and sediments) and biosphere (biota) [3, 8].

Thermal ionization mass spectrometry (TIMS) or multi-collector inductively coupled plasma mass spectrometry (MC-ICP-MS) are the most used techniques to measure $\mathrm{Pb}$ isotopic ratios from various matrices. One of the biggest disadvantages of these techniques are the high cost and the labor-intensive sample preparation in ultraclean laboratories [9]. However, the precision of single detector ICP-MS instruments is at least one order of magnitude poorer when compared to MC-ICP-MS methods, due to inherent sequential reading that is affected by plasma variations between readings. Single detector ICP-MS offers a higher versatility and lower initial and maintenance costs, and its precision can be considered satisfactory for some applications.

If not chemically separated, the ${ }^{204} \mathrm{Hg}$ isotope (mass 203.973476 amu), will overlap ${ }^{204} \mathrm{~Pb}$ isotope (mass $203.973029 \mathrm{amu}$ ) and separating them in a mass spectrometer requires a resolution of over 400000 . That is well beyond the limits of current instruments as the ICP-MS resolution varies from 400 for a single detector, quadrupole instrument, to around 10000 for a sector field instrument, which is 40 times lower than the required value to separate ${ }^{204} \mathrm{Hg}$ from ${ }^{204} \mathrm{~Pb}$ isotopes [10-12]. Thus, lead isotopic ratio studies are published incompletely, without specifying the ${ }^{204} \mathrm{~Pb}$ isotope, since ${ }^{204} \mathrm{~Pb}$ 
analysis is often unreliable. As chemical separation is a resource consuming step in sample preparation, recent advances in ICP-MS design makes it possible to have an online chemical sample alteration that removes the ${ }^{204} \mathrm{Hg}$, making ${ }^{204} \mathrm{~Pb}$ determination possible to an acceptable precision level.

In the case of ${ }^{204} \mathrm{~Pb}$ determination, a triple-quadrupole ICP-MS will filter out all the isotopes with masses different than 204 amu using the first quadrupole (Q1), leaving a mix of $\mathrm{Pb}$ and $\mathrm{Hg}$ passing through the rest of the mass spectrometer. The ion beam will enter the second quadrupole (Q2), that doesn't have a filtering role, but it guides the beam trough the collision/ reaction cell. The cell has the possibility to be pressurized with a collision and/or a reaction gas in case of the most ICP-MS instruments on the market. In this case, if the cell is pressurized with ammonia, it will react with ${ }^{204} \mathrm{Hg}^{-}$ ions much more often than with ${ }^{204} \mathrm{~Pb}$ - ions, transferring an electron to the $\mathrm{Hg}$ ions, rendering them neutral (due to instrument design, the ion beam in ICP-MS is usually made exclusively from negative ions). Thus, the third quadruple (Q3) will guide only the ${ }^{204} \mathrm{~Pb}$ ions to the detector, filtering out the remaining ${ }^{204} \mathrm{Hg}^{0}$ atoms [13], a process depicted in Figure 4.

The main objective of this study was to optimize the determination of $\mathrm{Pb}$ isotopic ratio from cave sediment samples, using triple-quadrupole ICP-MS instrument with reaction cell by pressuring with ammonia, in order create a neutral ${ }^{204} \mathrm{Hg}$ species that is filtered out from the ion beam. Cave sediment samples are considered to be significant part of caves science, offering valuable information about the caves hydrogeological and palaeoclimatological records. Take into consideration further application possibilities, cave samples were used as test samples for $\mathrm{Pb}$ isotopic ratio method optimization. Five different caves from Romania were selected in order to study the scattered distribution of $\mathrm{Pb}$ isotopic ratio from the sediment samples.

\section{RESULTS AND DISCUSSION}

The $\mathrm{Pb}$ concentration is displayed in Figure 1. The highest $\mathrm{Pb}$ content was measured in case of the sampling sites from Ferice cave $(19.4 \mathrm{mg} / \mathrm{kg}$ $\pm 4.53)$. High $\mathrm{Pb}$ values were found also in case of the sites from Lesu cave $(12.3 \mathrm{mg} / \mathrm{kg} \pm 0.84)$. The lowest $\mathrm{Pb}$ values were registered in case of Tausoare cave $(3.9 \mathrm{mg} / \mathrm{kg} \pm 1.28)$. 


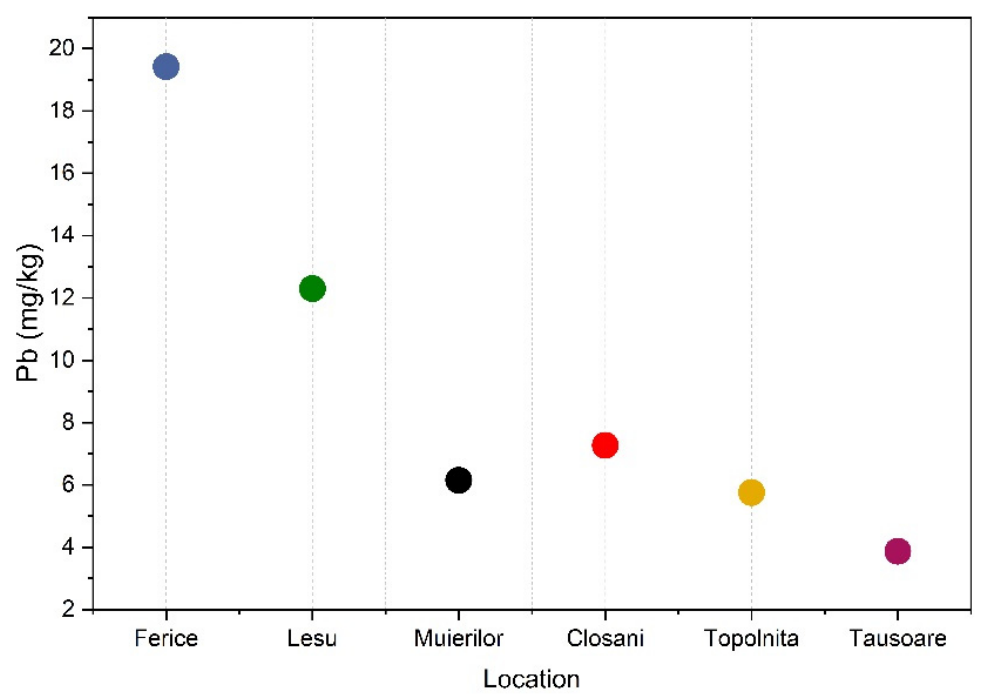

Figure 1. $\mathrm{Pb}$ concentration $(\mathrm{mg} / \mathrm{kg})$ in the cave sediment samples.

Table 1. Results of NIST 981 SRM reading for the $\mathrm{Pb}$ isotopes $(n=10)$

\begin{tabular}{|l|c|c|c|}
\hline & $\mathbf{2 0 4 / 2 0 6}$ & $\mathbf{2 0 7 / 2 0 6}$ & $\mathbf{2 0 8 / 2 0 6}$ \\
\hline Certified values & 0.059042 & 0.91464 & 2.1681 \\
(NIST 981 SRM) & \pm 0.000037 & \pm 0.00033 & \pm 0.0008 \\
\hline Average measured values & 0.059558 & 0.91817 & 2.1555 \\
(this study) & \pm 0.000865 & \pm 0.00842 & \pm 0.0062 \\
\hline
\end{tabular}

A batch of 10 measurements of NIST 981 standard reference material (SRM) was performed and the results are listed in Table 1. Uncertainty was calculated as three times the standard deviation. The uncertainty for ${ }^{204} \mathrm{~Pb} /{ }^{206} \mathrm{~Pb}$ is not significantly different from than ${ }^{207} \mathrm{~Pb} /{ }^{206} \mathrm{~Pb}$, but it's higher (at least one order of magnitude) than the one reported for NIST 981 SRM, due to differences in employed techniques (Figure 2). Relative standard deviation of measurements was between $0.36 \%-0.59 \%$. 
LEAD ISOTOPIC RATIO DETERMINATION IN CAVE SEDIMENTS USING TRIPLE-QUADRUPOLE ...

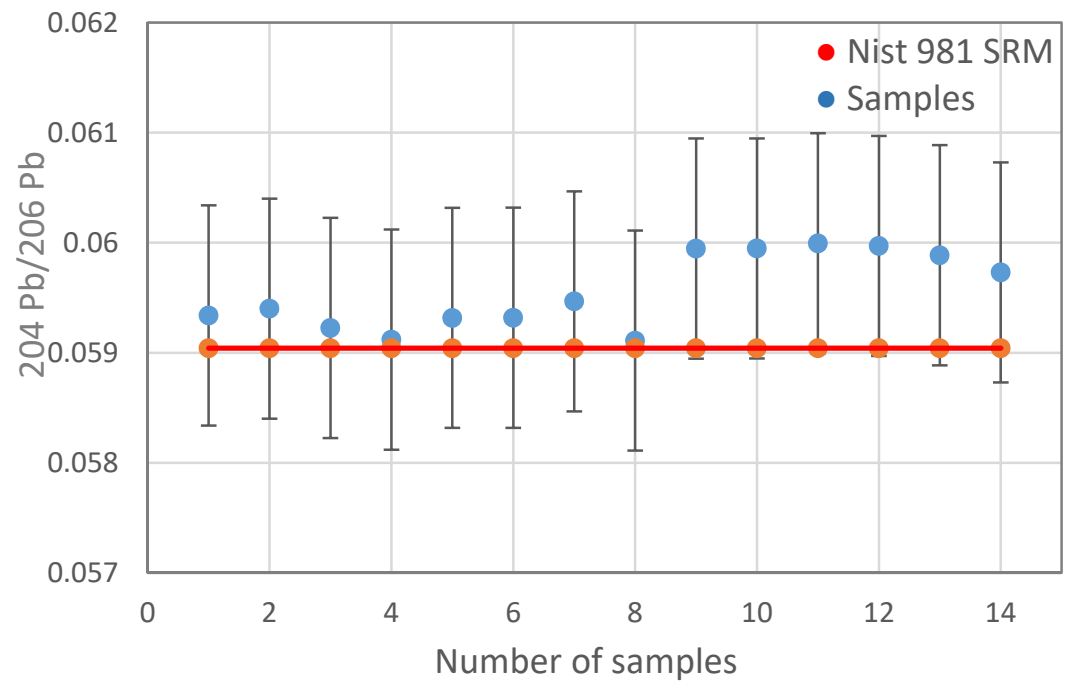

Figure 2. ${ }^{204} \mathrm{~Pb} / 206 \mathrm{~Pb}$ measured values (blue dots) and the NIST 981 SRM certified value (line).

The results for NIST981 measurements are displayed on Table 2 and graphically plotted on Figure 3 . $\mathrm{Pb}$ isotope ratio data shows a clear distinction between NIST 981 SRM and the rest of the sample, as expected, due to different analytical techniques used in this study (triple-quadrupole, singlecollector inductively coupled plasma mass spectrometry) and NIST laboratory (triple filament solid-sample mass spectrometry).

Table 2. Pb isotopic ratio in studied samples, including NIST 981 standard reference material for reference (5 readings/sample)

\begin{tabular}{|c|c|c|c|}
\hline Sampling sites & 204Pb/206Pb & 207Pb/206Pb & 208Pb/206Pb \\
\hline Ferice & $0.053859 \pm 0.0004$ & $0.846714 \pm 0.0051$ & $2.044527 \pm 0.0099$ \\
\hline Lesu & $0.05361 \pm 0.0001$ & $0.845489 \pm 0.020$ & $2.047661 \pm 0.048$ \\
\hline Muierilor & $0.052027 \pm 0.0017$ & $0.816579 \pm 0.0187$ & $1.992496 \pm 0.0353$ \\
\hline Closani & $0.052456 \pm 0.0001$ & $0.807570 \pm 0.020$ & $1.971243 \pm 0.035$ \\
\hline Topolnita & $0.054545 \pm 0.0001$ & $0.832732 \pm 0.0008$ & $2.006947 \pm 0.0017$ \\
\hline Tausoara & $\begin{array}{c}0.05491 \\
\pm 0.0002\end{array}$ & $0.83748 \pm 0.0024$ & $2.013048 \pm 0.0010$ \\
\hline NIST 981 SRM & $\begin{array}{c}0.059555 \\
\pm 0.001019\end{array}$ & $0.918095 \pm 0.009818$ & $2.145219 \pm 0.037757$ \\
\hline
\end{tabular}


ANAMARIA IULIA TÖRÖK, CLAUDIU TĂNĂSELIA, ANA MOLDOVAN, BOGDAN ANGYUS, ERIKA ANDREA LEVEI, CECILIA ROMAN

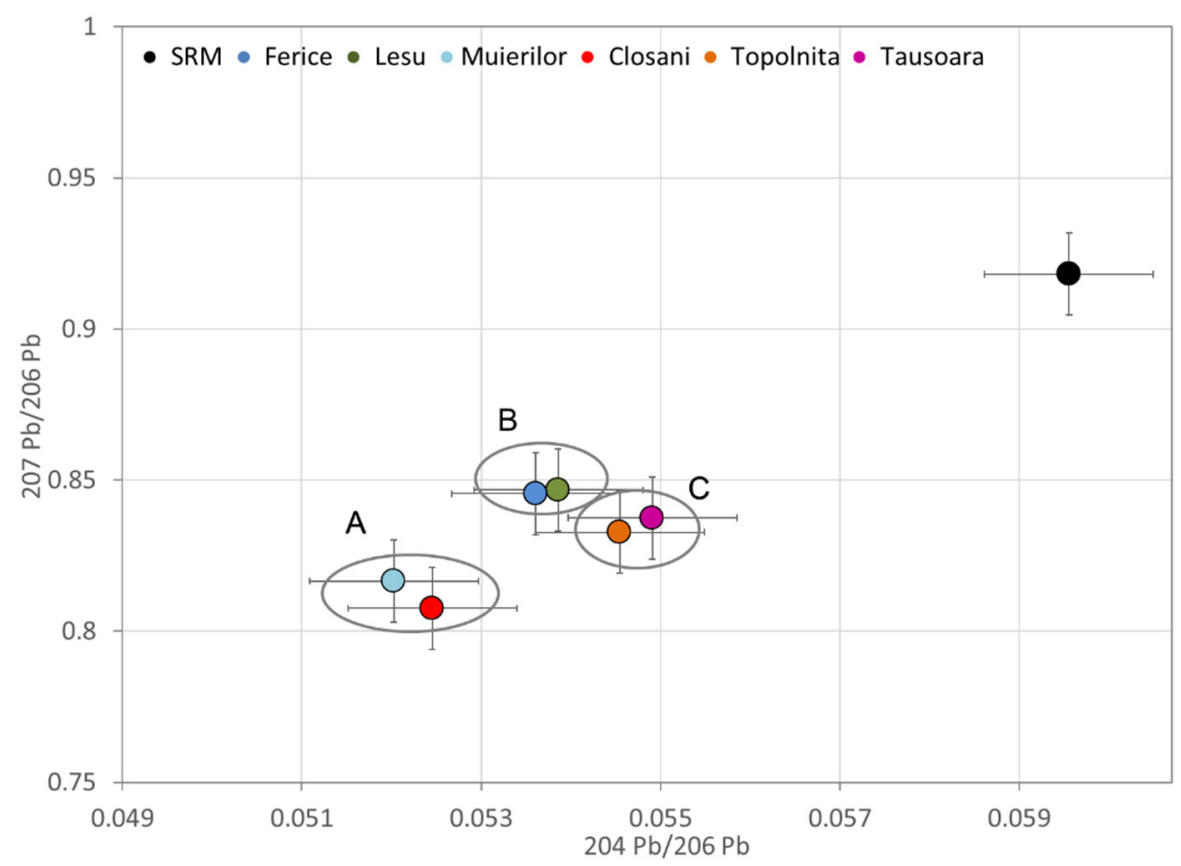

Figure 3. Sample results including NIST 981 SRM (top right): ${ }^{207} \mathrm{~Pb} /{ }^{206} \mathrm{~Pb}$ vs ${ }^{204} \mathrm{~Pb} /{ }^{206} \mathrm{~Pb}$ values. The error bars are calculated as three times standard deviations for each sample.

The samples from Muierilor and Cloșani (group A) are clearly separated from the other samples (Figure 3). Despite being sampled from different geographical locations, samples from Ferice and Leșu (group B) seems grouped together, as well Topolnița and Taușoare (group C) (Figure 3). A low separation between groups $B$ and $C$ is observed, but the isotopic ratio data doesn't show a clear distinction for samples within groups $B$ and $C$. This can be explained by insufficient precision, due to inherent plasma variation, associated with other geological factors that may be similar between the mentioned locations.

\section{CONCLUSIONS}

A triple-quadrupole ICP-MS was successfully used to determine $\mathrm{Pb}$ isotopic ratio from cave sediment samples, including data on ${ }^{204} \mathrm{~Pb}$, usually left out due to ${ }^{204} \mathrm{Hg}$ interference. The ${ }^{204} \mathrm{Hg}$ was removed in the reaction cell by pressuring the cell with ammonia, a reactive gas that would initiate a 
charge transfer to ${ }^{204} \mathrm{Hg}$, creating a neutral ${ }^{204} \mathrm{Hg}$ species that is filtered out from the ion beam. While further optimizations could improve the precision, this will remain an order of magnitude lower than multi-collector ICP-MS instruments, due to design limits. However, the achieved precision using this approach is satisfactory in some cases, especially if we consider the advantages of single collector ICP-MS (versatility, low initial and tunning costs) over more expensive and less flexible multi-collector ICP-MS instruments.

\section{EXPERIMENTAL SECTION}

\section{Instrumentation}

The $\mathrm{Pb}$ concentration and isotopic ratio measurements were performed using a Thermo Scientific iCAP TQ ICP-MS instrument. In order to minimize the effect of plasma variations, the dwell time was set to 0.02 seconds for ${ }^{208} \mathrm{~Pb}, 0.04$ seconds for ${ }^{206} \mathrm{~Pb}$ and ${ }^{207} \mathrm{~Pb}$ and respectively 0.2 seconds for ${ }^{204} \mathrm{~Pb}$, to increase the number of counts for the least abundant isotope, while keeping the counts low enough for the most abundant isotope so that the detector would stay in ion counting mode and won't switch to analog (Faraday) mode. For each isotope, one channel was used for reading its counts ("peak-hopping"). The number of sweeps was set to 250. Both Q1 and Q3 quadrupoles were used in "high resolution" mode, while the collision cell gas flow was set to $0.6 \mathrm{ml} / \mathrm{min}$. Nickel cones were used for all the measurements in this study and the instrument was configured in "HighMatrix" mode. Data acquisition and ICP-MS operation were performed using Qtegra software (v. 2.10.3324.131), provided by the manufacturer. ICP-MS operating parameters are listed in Table 3.

Table 3. Thermo Scientific iCAP TQ ICP-MS parameters

\begin{tabular}{|l|c|}
\hline ICP-MS parameter & Value \\
\hline Nebulizer gas flow (Ar) & $0.90 \mathrm{I} / \mathrm{min}$ \\
\hline Ammonia reaction gas for the remove of ${ }^{204} \mathrm{Hg}$ & $0.6 \mathrm{I} / \mathrm{min}$ \\
\hline Extraction Lens & $-132.1 \mathrm{~V}$ \\
\hline Spray chamber temperature & $2.7^{\circ} \mathrm{C}$ \\
\hline Q1 Focus Lens & $-1 \mathrm{~V}$ \\
\hline Q1 Bias & $-0.9602 \mathrm{~V}$ \\
\hline QCell Bias & $-2.01 \mathrm{~V}$ \\
\hline Q3 Bias & -1.0002 \\
\hline Focus Lens & $19.20 \mathrm{~V}$ \\
\hline RAPID Lens & $-377 \mathrm{~V}$ \\
\hline Plasma power & $1550 \mathrm{~W}$ \\
\hline Cool Flow & $14 \mathrm{l} / \mathrm{min}$ \\
\hline Auxiliary Flow & $0.8 \mathrm{I} / \mathrm{min}$ \\
\hline
\end{tabular}




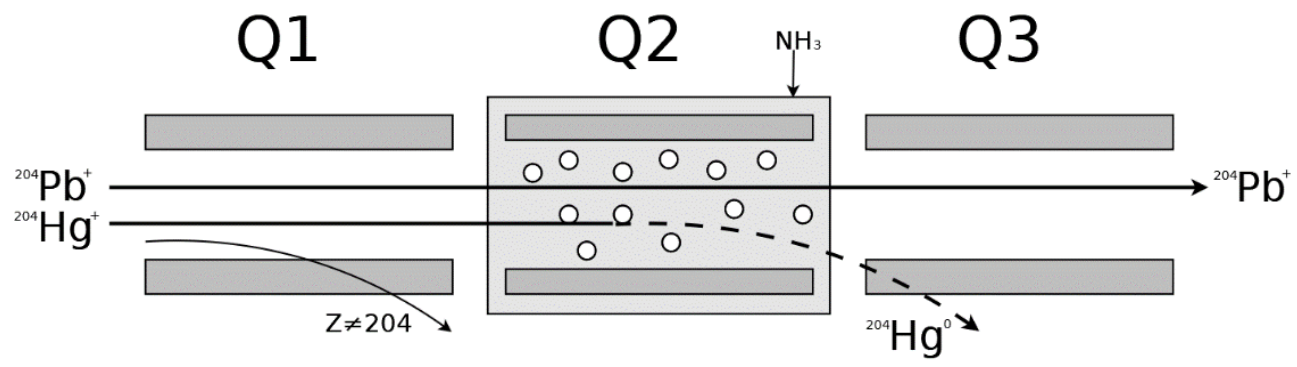

Figure 4. Removal of ${ }^{204} \mathrm{Hg}$ interference using a triple-quadrupole ICP-MS.

Q1- first quadrupole, Q2- second quadrupole (inside the reaction cell pressurized with ammonia) and Q3- third quadrupole.

\section{Description of SRM and cave sediment samples}

For measuring the total $\mathrm{Pb}$ concentration, a calibration curve was used in the $1-100 \mu \mathrm{g} / \mathrm{L}$ range and ${ }^{208} \mathrm{~Pb}$ was chosen, due to is highest abundance. The standard solutions for the calibration curve were prepared by successive dilutions from Perkin-Elmer Multi-Element Calibration Standard 3. For isotopic ratio calibration and to calculate the method uncertainty for each isotopic ratio, a NIST 981 standard reference material (SRM) was used. Blank values were subtracted from each measurement. The SRM was used in a bracketing technique: the reference material was measured before and after each sample, to avoid any signal shift in isotopic determination. Ultrapure deionized water from a water purification system (Elga Veolia, UK) with $\mathrm{HNO}_{3}(5 \%)$ was used for the blank samples and the $\mathrm{Pb}$ counts were measured and subtracted from the subsequent sample values. The deionized water was also used to prepare the calibration standard solutions and for all dilutions. The sediment samples were dried at $60-65^{\circ} \mathrm{C}$ for $12 \mathrm{~h}$. The dried samples were ground and sieved in order to obtain a fine powder. Three grams of the ground samples were dissolved in a 3:1 (v/v) mixture of $\mathrm{HCl}(30 \%)$ and $\mathrm{HNO}_{3}(65 \%)$ on sand bath, then transferred and diluted with ultrapure water to a final volume of $100 \mathrm{~mL}$ in volumetric flask. NIST 981 SRM was acquired as a solid sample (wire) and it was purchased directly from NIST. For analysis, $1 \mathrm{~g}$ of the solid sample was digested in $\mathrm{HNO}_{3}(65 \%)$ and $1 \mathrm{~L}$ stock solution was prepared, the diluted for daily use (down to $50 \mu \mathrm{g} / \mathrm{L}$ ).

The sediment samples were collected in February 2020, from five Romanian caves: Ferice, Lesu, Muierilor, Tausoare, and Topolnita sampling sites. 


\section{ACKNOWLEDGMENTS}

This work was supported by the Romanian Ministry of Research and Innovation, CCCDI-UEFISCDI, through projects 352PED/2020 (GLAZEX) and PN-III-P4-ID-PCCF-2016-0016 (DARKFOOD) within PNCDI III. The authors would like to thank Dr. Oana Teodora Moldovan for providing the samples collection.

\section{REFERENCES}

1. F. Vanhaecke K. Kyser, The Isotopic Composition of the Elements, in Isotopic Analysis. 2012. p. 1-29.

2. D. Weis, Lead Isotopes, in Encyclopedia of Geochemistry: A Comprehensive Reference Source on the Chemistry of the Earth, W.M. White, Editor. 2017, Springer International Publishing: Cham. p. 1-5.

3. A.M. Ghazi J.R. Millette, 4 - Lead, in Environmental Forensics, R.D. Morrison and B.L. Murphy, Editors. 1964, Academic Press: Burlington. p. 55-79.

4. R.D. Vocke; Pure Appl Chem, 1999, 71, 1593-1607.

5. L. Gao, L. Han, W. Peng, B. Gao, D. Xu; X. Wan; Ecotoxicol Environ Safety, 2018, 164, 226-233.

6. H. Cheng Y. Hu; Environmental pollution (Barking, Essex : 1987), 2010, 158, 1134-46.

7. A.L. Wani, A. Ara; J.A. Usmani; Interdisciplinary toxicology, 2015, 8, 55-64.

8. J. Zhou, B. Du, Z. Wang, W. Zhang, L. Xu, X. Fan, X. Liu; J. Zhou; Sci Total Environ, 2019, 647, 932-941.

9. B. Gulson, G.D. Kamenov, W. Manton; M. Rabinowitz; Int J Environ Res Public Health, 2018, 15, 723.

10. I. Gelaude, R. Dams, M. Resano, F. Vanhaecke; L. Moens; Anal. Chem., 2002, 74, 3833-3842.

11. G. Audi A.H. Wapstra; Nuclear Physics A, 1995, 595, 409-480.

12. I. Gelaude, R. Dams, M. Resano, F. Vanhaecke; L. Moens; Anal Chem, 2002, 74, 3833-42.

13. D. Asogan. Using triple quadrupole interference removal to improve data quality in laser ablation ICP-MS for geochemical applications. Application note 44387 2018; Available from: https://assets.thermofisher.com/TFS-Assets/CMD/ Application-Notes/an-44387-icp-ms-interference-removal-geochemicalan44387-en.pdf. 
